\title{
John Marenbon, Pagans and Philosophers: The Problem of Paganism from Augustine to Leibniz
}

\section{Alfonso Herreros Besa}

\section{(2) OpenEdition}

\section{Journals}

\section{Electronic version}

URL: http://journals.openedition.org/medievalista/1289

DOI: 10.4000/medievalista.1289

ISSN: 1646-740X

\section{Publisher}

Instituto de Estudos Medievais - FCSH-UNL

\section{Electronic reference}

Alfonso Herreros Besa, "

John Marenbon, Pagans and Philosophers: The Problem of Paganism from Augustine to Leibniz », Medievalista [Online], 21 | 2017, Online since 01 June 2017, connection on 23 September 2020. URL : http://journals.openedition.org/medievalista/1289; DOI : https://doi.org/10.4000/medievalista.1289

\section{(c) (7) (8)}

Mediavalista está licenciado com uma Licença Creative Commons - Atribuição-NãoComercial 4.0 Internacional. 
Título / Title: Review: MARENBON, John - Pagans and Philosophers: The Problem of Paganism from Augustine to Leibniz. Princeton: Princeton University Press, 2015 (xi + 354 pp.) Autor(es) / Author(s): Alfonso Herreros Besa Universidade / University: Universidad de los Andes Faculdade e Departamento / Unidade de Investigação - Faculty and Department / Research Center: Instituto de Filosofía Código Postal / Postcode: 7620001

Cidade / City: Santiago

País / Country: Chile

Email Institucional / Institutional email: ajherreros@miuandes.cl

Fonte: Medievalista [Em linha]. Direc. Bernardo Vasconcelos e Sousa. Lisboa: IEM. Disponível em: http://www2.fcsh.unl.pt/iem/medievalista/MEDIEVALISTA21/besa2107.html ISSN: 1646-740X

Data de recepção do texto / Received for publication: 25 de Julho de 2016 


\section{Review: MARENBON, J ohn - Pagans and Philosophers: \\ The Problem of Paganism from Augustine to Leibniz. Princeton: Princeton University Press, 2015 (xi +} 354pp.)

Alfonso Herreros Besa

Is divine assistance, grace, necessary for knowing God? Can anybody develop virtues? Is salvation open to everybody - or only for Christians? Marenbon sets forth in this book the answers given to these three questions, which are labeled as "The Problem of Paganism”, a coinage, he claims, of his own.

He does not aim with this study to resolve them. In fact, Marenbon apparently doesn't think that they still pose a problem, even though he avows his personal interest in the subject and recognizes some similarity with modern topics (tolerance, religious difference and relativism). Instead, he describes his work as the output of a method called "Historical Synthesis" as opposed to "Historical Analysis". The latter, he tells us, takes an actual theoretical problem and scrutinizes how authors of the past tried to solve it, whereas, through the former, the historian synthetizes heterogeneous texts (philosophical, theological, literary, travel-records, ethnographical...) in order to trace the existence and handling of a problem that puzzled bygone thinkers.

Marenbon attempts to support, through this synthesis, what he calls "The Long Middle Ages”, i. e. a heuristic device showing how the Middle Ages (at least in the Latin world) started at the $4^{\text {th }}$ Century and persisted up to the dawn of the $18^{\text {th }}$ century, and perhaps beyond, in the sense of having conserved roughly the same principles for understanding reality and facing its problems. As a result, he thinks, his skeptical understanding of 
history is demonstrated: history isn't an intelligible and purposeful totality divisible through periods, but rather a continuous flow of people confronted with similar issues for example, what we are to do with pagans. In other words, he will try to set out a series of authors who similarly responded the questions raised at the start of this review and, if he manages to do that convincingly, it will be an important (but obviously insufficient by itself) support for reasonably lengthening the Middle Ages.

Does he succeed at justifying the "Long Middle Ages" thesis? So far as the continuity of the "Problem of Paganism" into the Modern Age goes, yes. Of course, the Middle Ages cannot be defined only in terms of this topic, but at least his account on this subject does help to legitimize his proposal. His compelling narrative of how medieval thinkers confronted the topic is supported by a rich gamut of authors, ranging from strict theologians such as Aquinas and Suárez to travelers like John Mandeville, to poets like Dante and Chaucer. This topic had such a widespread treatment, Marenbon explains, because it was not only an abstract theological disquisition, but a dilemma about the salvation of wise men like Aristotle, heroes like Cato or good barbarians like the newly discovered Americans, without contradicting the tenets of faith. His discussion of each of them, save some especially important authors, is not particularly detailed, which is to be expected from a three hundred pages book dedicated to a historical span of about 1400 years. This condensed method helps to picture the whole deal of paganism as studied in the Middle Ages, and Marenbon ideates some valuable categorizations to smoothly organize the book. In spite of that, it must also be pointed out that the distinction between different writers tends to blur out when the author describes them, even when he tries to stress the "originality" of a given thinker.

Marenbon appeals to the philosophical commonplace (not necessarily a wrongthing to do) of the "explorer": after paving the way for the future generations, other researches will fill in the details. Taking into consideration this first approach focus, and that he only wants to demonstrate the plausibility of talking about a "Long Middle Age", Marenbon has divided his book into three sections.

The first of them describes how the Problem of Paganism in the Latin Christian Europe took its fundamental shape in Late Antiquity, essentially through the writings of 
Augustine and Boethius. Augustine deeply determined the discussion by stressing the need of grace for virtue and salvation, even if he concedes the deepness of pagan knowledge of God. Boethius was far more lenient by thinking that Lady Philosophy was conscious of her need of faith, and therefore championing the continuity between Revelation and reason.

The second and thickest section examines the period of time traditionally designated as the Middle Ages, that is, from the Carolingian Renaissance to the $15^{\text {th }}$ Century. To list all the writers examined by Marenbon and his reflections on each of them goes beyond the scope of this review. His narrative is made accessible thanks to categorizations he ideates when treating the branches of the Problem of Paganism. When speaking of pagan knowledge of God, three types appear: Unity (both reason and faith originate from God, so they cannot contradict themselves, therefore entailing the capacity of Philosophy for knowing God), selective rejection (pagan knowledge offers a framework which needs the correction and guidance of faith to fulfill itself) and limited relativism (truths reached necessarily by reason under different sciences may be considered false when taking faith under consideration).

Virtues generally receive what the author denominates an Augustinian relativistic approach, maintained by Abelard, amid others: they are not true virtues, due to their absence of charity, but are nevertheless real virtues from a natural point of view. Salvation for pagans is differently theorized, stretching from those who condemned them without much ado, to some who postulate early contact with the Old Testament or individual revelations just before death, and finally to those who thought that pagans could be saved by following natural law and having an implicit faith in the Incarnation. The examination of this period gives some really interesting insights on travel diaries, ethnographic treatises and apologetics of pagans from the East or America. He also looks through literary authors; in one chapter he briefly studies Bocaccio and largely discusses on Dante's contribution to the Problem of Paganism; afterwards he analyses Langland and Chaucer in a chapter somewhat confusing owing to the poetical, nonargumentative style of these English writers. 
The third and last part of the book serves to substantiate the thesis of a "Long Middle Ages” regarding paganism, i. e. that, notwithstanding the discoveries of pagans living after Christ and the new political and scientific challenges, the principles for understanding pagans remained fundamentally the same at least until 1700 . The chapter on pagan knowledge of God expounds on the theories developed outside universities, with a special emphasis on the surprisingly harsh humanists and the discussions of Spaniards regarding the American idolatries. On pagan virtue, the scholastic tend to develop Aquinas' opinion, according to which virtuous actions made by pagans are in certain way really good when directed to a natural good end, for it can be subsumed into God's order. Humanists and Protestants tend to be even harsher than Augustine. Concerning their Salvation, the aforementioned theories were still in use for a long time. The vast amount of writings studied in Pagans and Philosophers makes this book useful primarily for scholars researching on the intellectual history of the West as rooted in the Christian Middle Ages, and also for those who would want to read a historical introduction to the theological topic of grace. For those investigating on topics such as knowledge and virtue as understood by Augustine, Abelard or Dante (the other medieval authors studied here receive too little treatment for an honest discussion with the author's position), Marenbon's perspectives offer an interesting insight.

As a way of conclusion, two considerations could be made on the author's theoretical approach to the subject. First, the modest objective of only showing the plausibility of talking about the "Long Middle Ages" deviates the attention from the central issue for medieval authors: is virtue, knowledge of God and Salvation reserved only for Christians? Why or why not? As mentioned at the start, he seemingly thinks it is a noproblem, and he even hints at the general conclusion that it is a completely intractable issue, where no conclusive results can be reached (something reserved in his view only for the natural sciences). This is a highly arguable assumption. Second, his label "relativism” for the conception of pagan virtues of many writers is anachronistic, not to say completely misguiding when considering that the problem for these authors were not the kind originated in Europe after the Religion Wars, but one of a more metaphysical kind, to label it somehow: how is Christianity accessible to those who have not had the opportunity of receiving baptism, if Christian Faith is the universal way of Salvation? In what manner nature without grace is enough for happiness? The 
concept of analogy is better suited to make the position of many authors understandable - that is to say, knowledge, virtue and maybe salvation are real, in a different, yet similar, sense by which the supernatural order is absolutely real. Even conceding, for example, that Augustine is too harsh with heroic pagans, his final judgement of pagan goods does permit some real virtues on its own order, as illustrated by his discussion on the pagan republic ${ }^{1}$. It is feasible to demonstrate that Aquinas ${ }^{2}$ would also defend a consideration of pagan virtue as real goods ${ }^{3}$, even though supernatural charity is still required for full human perfection. Notwithstanding this disagreement, Marenbon's book undeniably contributes with his synthetic approach to the study of medieval philosophy and theology from a general perspective, helping therefore to figure out a common pattern for understanding and interpreting this period.

\section{COMO CITAR ESTE ARTIGO}

\section{Referência electrónica:}

HERREROS BESA, Alfonso - "Review: MARENBON, John - Pagans and

Philosophers: The Problem of Paganism from Augustine to Leibniz. Princeton:

Princeton University Press, 2015 (xi + 354pp.)”. Medievalista 21 (Janeiro - Junho

2017). [Em linha] [Consultado dd.mm.aaaa]. Disponível em

http://www2.fcsh.unl.pt/iem/medievalista/MEDIEVALISTA21/besa2107.html

ISSN 1646-740X.

\footnotetext{
${ }^{1}$ AUGUSTINUS, Sanctus Aurelius - De Civitate Dei. Ed. Bernardus Dombart et Alfonsus Kalb. Vol. II, lib. XIV-XXII. Stutgardiae et Lipsiae: Aedibus B. G. Teubneri, 1993, IX, pp. 21-25.

${ }^{2}$ See for instance AQUINATIS, Sancti Thomae - Secunda secundae Summae theologiae. Opera omnia iussu impensaque Leonis XIII P. M. edita, t. 8-10. Romae: Ex Typographia Polyglotta S. C. de Propaganda Fide, 1895-1897-1899), q. 110, a. 3, co; Quaestiones disputatae de virtutibus cardinalibus. Ed. E. Odetto Quaestiones disputatae, t. 2, pp. 813-828. 10a ed. Taurini-Romae: Marietti, 1965, q. 5, a. 4, co.

3 A precise exposition of the views from both medieval authors is found in IRWIN, T. H. - "Splendid Vices? Augustine for and against Pagan Virtues”. Medieval Philosophy and Theology 8 (1999), pp. 105-127.
} 


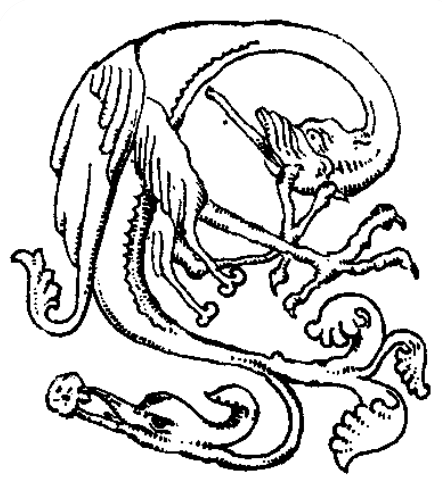

